\title{
Political Corruption and the Future of Nigerian Politics
}

\author{
Adegboyega O. Oyekunle ${ }^{1}$ \\ ${ }^{1}$ Department of Philosophy, Olabisi Onabanjo University, Ago-Iwoye, Nigeria \\ Correspondence: Adegboyega O. Oyekunle, Department of Philosophy, Olabisi Onabanjo University, Ago-Iwoye, \\ Ogun State, Nigeria. E-mail: Oyekunle2006@yahoo.com
}

Received: March 3, 2015 Accepted: April 16, 2015 Online Published: October 29, 2015

doi:10.5539/ilr.v4n1p178

URL: http://dx.doi.org/10.5539/ilr.v4n1p178

\begin{abstract}
The purpose of this paper is to examine the effects of political corruption on the Nigerian society. It examines the future of the political status of Nigeria given the present experiences in the polity. The paper employs the analytic and critical method of philosophy, with a view to showing the influence of Machiavelli's political philosophy on the Nigerian political elites. The central argument of this paper is that the interpretation of politics in the Machiavellian way, its adoption and practice by Nigerian political elites stand as the root cause of political corruption in the country.
\end{abstract}

Keywords: Machiavelli, national development, Nigeria, political corruption, politics

\section{Introduction}

The Nigerian society is characterized by low rate of national development. This ensues from the high level of political corruption in the country. Political corruption involves political leaders and other public officials who run the affairs of a state. It is a phenomenon that has negatively affected the body politic of the Nigerian state. The euphoria of the 1960 Independence had since been buried and the hope of realizing the attending promises of peace, unity, order, justice and development remain uncertain. In point of fact, the question that agitates the mind is; can Nigeria ever be free from the virus of political corruption? The need to answer the question is fundamental to the future of Nigerian politics. This is because an overview of the Nigerian nation shows that the virus is endemic in the nature of some political elites in Nigeria.

Our task in this paper is to critically examine the effects of the phenomenon of political corruption on the Nigerian politics. The paper upholds the thesis that the future of Nigerian politics depends on the political elite's readiness to jettison the Machiavellian interpretation of politics, which they have imbibed and practised over the years and embrace the normative conception of politics.

The paper is divided into five parts. The first part is a conceptual clarification of the ideas of political corruption, public immorality and Machiavellian conception of politics, (hereinafter referred to as Machiavellianism). The second part is an overview of Machiavelli's political philosophy and the Nigerian situation. The third part examines the effects of Machiavelli's philosophy on Nigerian politics. The fourth part is a critical evaluation of Machiavellianism and public morality in Nigeria. The fifth part is the conclusion of the paper.

\section{Nature of Public Morality, Political Corruption, Public Immorality and Machiavellianism}

\section{1}

Public morality can simply be defined as the principle of behaviour that is right and good, which ought to be exhibited and approved by society. When practised, it places the state or society on a ground of peace, orderliness and in the end achieves "the good end", which is the ultimate goal for which the state is created. Public morality helps in the enhancement of the security of the rights of individuals to life, liberty and the pursuit of happiness by individuals without impinging on other people's rights. It is the prevalent opinions as to right and wrong in public conduct; that is primarily in the conduct of governments, whether in relation to the members of the state or by extension in its dealing with other states (Sidgwick, 1984, 5).

This notion can be extended to include the conducts of private individuals, since they also exert some sorts of influence on the governance of the state. Thus, public morality is an essential factor to all the parties in the state, that is, both the citizens and the body that is responsible for the administration of the state. This suggests then, that politics and morality ought not to be separated. This position is premised on the understanding of morality as 
the of standard of good behaviour and on politics, which can be described as the activities of individuals in so far as they impinge on the public realm made up of collective interests of the citizenry. (Ekeh, 1975, 91-112).

Public morality is the attainment of the norms of ethics. To this effect, Kola Owolabi $(1995,2)$ notes that public morality "is the set of normative rules guiding the interactions of man in the polity." It can also be seen as "those complex norms of behaviour and social practices which may have profound effects upon the lives of a number of people in the community and thereby affect their communal existence" (Owolabi, 1995, 3). The underlying assumption in the idea of public morality is that human behaviour in relation with others must conform to certain standards. Without any moral principles and regulations that guide the relationship among human persons in a given state, growth and social order, which are two necessary ingredients for the satisfaction of the good life, cannot be realized.

Suffice to say that the absence of public morality is called public immorality or political corruption. This is a situation where an individual neglects the public interests and gives attention to the satisfaction of his or her desires and interests. According to H. H. Werlin (1972, 395), public immorality and political corruption are "signs of fundamental political disorder". These manifest in multifarious ways; among which are nepotism, kickbacks, favouritism, fraud, selfishness, embezzlement of public funds and many other political vices.

It may be difficult to make sharp distinction between public immorality and political corruption, since both touch the lives of the citizens of a state on the same principle; that is, on the principle of rightness or otherwise of actions. Furthermore, the word "political" means "public" (non-private) or official. Political corruption is the kind of corruption that involves rulers and other public officials who run the affairs of a state or a political community. It is "an act of corruption perpetuated against the state or its agencies by person(s) holding an official position in pursuit of his or her own private or personal profit" (Dukor, 2003, 387). The point is, any corrupt act committed against a private or nongovernmental organization will not be regarded as political corruption, even though it is an act of corruption. Public immorality is characterized by social vices that affect development in any given state. Such vices are antithetical to the nature of human being and society. The vices militate against the general well-being, happiness and self-fulfillment of the people.

\subsection{Machiavellianism}

"Machiavellianism" means the practice of Niccolo Machiavelli's socio-political philosophy. What runs through the mind when we study Machiavelli's (1999) book The Prince is the presentation of politics in an amoral sense. His opinion is that, in politics, any means employed can only be justified by the realization of the desired goal. His view implies that the essential thing in politics is to try to grab power by all means: fair or foul. Having grabbed power, it must be retained at all cost. Thus, to Machiavelli, and some other political philosophers, what is central to the idea of politics is the acquisition of power. However, there is a difference between him and others in the mode by which the political power can be acquired. To most political philosophers, power must be acquired through the people's consent and with absolute moral consideration (Ogunmodede, 1986, 40 \& Raphael, 1982, 54-57). To Machiavelli, political power can be acquired through any of the following; through war, through one's arms and skill, through the arms of others and fortune, through wickedness and nefarious means and through the favour of one's fellow citizens. In all of these means, Machiavelli does not give any consideration for morality. His view shows that, to be successful in politics, one should simply ignore morality and use amoral means. What is important is that one succeeds in the end. The success of the acquisition, retention and expansion of power to Machiavelli, is very crucial for it is the standard (the only standard) by which all political actions are judged.

\section{Machiavelli's Political Philosophy and Politics in Nigeria}

The above-stated observations about Machiavelli, characterize the past and present political conditions of Nigeria, where politics have been practiced in an amoral sense. The acquisition of political power since independence, has always taken after Machiavellian politics. In a way, we can identify two ways by which political power has over the years been acquired in Nigeria. They are: one, through democratic means. Activities that surround this means of acquiring power raise a fundamental moral and legal question. It also generates the question as to whether the acquisition of this political power by the leaders was truly democratic. Were democratic values like freedom of choice of candidates at elections, rule of law; independent electoral body; free and fair elections and so on adhered to? An observation of events in Nigeria has shown that thuggery, use of money, molestation, threats, rigging, and all forms of electoral malpractices were employed to win and secure political power. All these means abound in Machiavelli's examination of what politics is, and most importantly, they constitute what he regards as virtues that can be employed in the art of political practice. Like Machiavelli, politicians have been so shrewd, swift, violent and brutal in their efforts to acquire political power. To 
corroborate the above assertion on the experiment of Machiavellian principles since independence, Omoregbe (1993, 131), contends that: "First, most elections are not free and fair. All elections we have been conducting since independence have been shams, with their outcome manipulation."

Thus, Nigerian politicians profess to be democratic when indeed they are devoted to Machiavellian principle. Machiavellian principle as observed undermines democratic values and principles. In democracy, the acquisition of power and its retention places optimum consideration on morality. Another important fact that must be acknowledged is that in Machiavellianism, the power acquired has been observed not to have anything to do with the enhancement of the common good but selfish purpose (Machiavelli, 1999, 20-22). Politics, when practised in this manner, is regarded as amoral politics. It is this amoral sense of politics that informs the definition of politics as "strife of interests masquerading as a contest of principle, the conduct of public affairs for private advantage" (Owolabi, 1995, 8).

In Nigeria, most leaders see power as an end in itself and, therefore, use any means, foul or fair, to acquire it. It has become a difficult task for most politicians to isolate political corruption from political virtue. The situation is the same with those who came to power through the arms of others and fortune (Machiavelli 1999, 20-22). In this case, those who assisted others in winning political power have become political godfathers. Experience has also shown that such leaders have to respect the wishes and demands of their godfathers who would want nothing else than to regain and make profit on the "investment" they have made on the political leader. Those who have attempted to refuse and resist their political godfathers' wishes and demands have always lead their society into chaos, and are also removed from the position of power thereby creating confusion and instability. In the contemporary Nigerian society, Rasheed Ladoja and Chris Ngige who were governors of Oyo State (Ajanaku, 2006) and Anambra State (Agbonifo, 2012) respectively during the Third Republic suffice as examples.

The second means by which political power has been acquired in Nigeria is through coup d'etat. It is usually perpetrated by the military. This in Machiavelli's language means 'power acquired through wickedness and nefarious means' (Machiavelli, 1999, 27-31). Machiavellianism approves this mode of acquiring power if and only if the end goal is attained. However, we contend that power acquired through coup d'etat is immoral and condemnable.

It is imperative to say that the military has over the years become politicized and corrupt. The military has systematically damaged the political situation, and driven the nation into stagnation socially and economically. Various means were employed by the military to retain themselves in power. They operated a framework of their own; posed their own standard of judgment; made and used decrees rather than the constitution; showed no regard for human freedoms and rights and employed other forms of immoral methods such as killing and imprisonment to retain themselves in power (Etim \& Wilfred, 2012: 285-292).

The acquisition of power through coup d'etat is both illegal and immoral. It is illegal because such acquisition of power is unconstitutional, except when it is backed by decree after the acquisition. It is immoral because it lacks the support of the citizens. It suffices to say that when political power is not acquired through legal and moral means the demand for moral and political obligations from the citizens become questionable. This, therefore, explains why individual members of the society would also consider it expedient to employ any means to help themselves out of the precarious conditions that they may find themselves. Little wonder, therefore, that the whole society seems to have been invested with the virus of immorality that echoes in the teaching of Machiavelli.

Since the leaders employ immoral means to acquire or retain power in order to pursue their personal interests, the citizens have also been employing any means, foul or fair, to sustain themselves in the already polluted society. For them to survive, while some resort to bunkering and vandalisation of oil and gas pipelines (Shosanya 2009), some others recourse to kidnapping for ransom (Alemika 2012). The moral feelings of the public have been negatively affected and so the public can no longer justify the actions of the political system. When the public begins to accept certain political actions and organizations as discordant with the moral feelings, it is an indication of an emerging crisis in the society. This is exactly the situation with the Nigerian society where morality has been politicized.

Political leaders in Nigeria, in a Machiavellian manner, give pretence to morality when contesting for power, and also give little or no attention to public good or interest in their attempt to retain power. To a large extent, virtues are abhorred and vices are promoted. The attending effects of all these are seen in leaders becoming perpetrators of injustice, treasury looters, or becoming unfaithful, law flouters, tyrants, despots and so on. It seems to us therefore, that once a person gets involved in politics, he or she becomes an immoral person. This is why some people regard politics as a dirty game (Walker, 1975, 102-103). 
Machiavellianism provides us an understanding of the diabolical nature of most Nigerian leaders. Military and civilian leaders use both the nature of the lion and that of a fox as suggested by Machiavelli. The lion is known for its bravery and bestiality, while the fox is known for its shyness. In certain occasions, they act the fox by pretending to be what they are not in order to achieve their end, and in some other occasions they act the lion and so become callous to retain themselves in power.

The military, after acquiring power, pretend to be good and act like a rescue force (Ademoyega, 1981). Only after a while they began to issue series of draconian decrees that the citizens could not oppose. Those that opposed or flout these decrees were jailed and sometimes killed (Ekeh, 1998). Chiefly among these military rulers are Generals Olusegun Obasanjo, Ibrahim Badamosi Babangida, and Sanni Abacha. The main problem, however, is that they, on the long run, became guilty of the crime they asserted they had come to address. They amass wealth to themselves at the expense of the public. For instance, the regime of General Olusegun Obasanjo between 1976 to 1979 commenced an agricultural programme tagged Operation Feed the Nation (OFN) but little did we know that it was a deceit, as the programme eventually became his private farm, Obasanjo Farms Nigeria (OFN) (Adegboyega, 2012, 5). The probe in the House of Representative in 2009 also reveals the various shady and unimplemented contracts approved and paid for between 2003 and 2007 by his regime (International Herald Tribune, 2008). Aside, the question of how the Petroleum Trust Development Fund (PTDF) money was spent remains an unanswered question between him and his Vice President, Alhaji Atiku Abubakar (Fagbemi, 2007). Babangida's regime, between August 27, 1985 and November 16, 1993, could not account for 12.4billion dollars of oil windfall that was made during his regime (Gboyega, 1996, 34). General Sanni Abacha ruled the country between November 17, 1993 and June 1998. After General Sanni Abacha's demise in 1998, billions of dollars were recovered from some of his bank accounts within and outside the country as well as his house, which are part of the loots from the Nigerian treasury (Pieth 2008, 43-44). The above-stated remarks are just few examples of some of the ways the leaders perpetuate corruption in Nigeria and the citizens are made to suffer.

\section{Effects of Machiavelli's Political Philosophy on Nigerian Politics}

The reason why politics is completely amoral in the contemporary Nigerian nation is not because of the kind of politics inherited from the colonial masters, but because of successive leadership's determination to embrace Machiavellianism. Machiavelli's political doctrine does not only suggest the acquisition of political power through immoral means, it also absorbs political leaders from every form of immorality once their action is directed towards the realization of the leader's goals or objectives. Thus, the various political killings of Engineer Funsho Williams, (Punch, 2006); Dr Ayodeji Daramola, (PM News, 2006 ), Dipo Dina, (Punch, 2010 ) and many others do not matter morally within the political context. The unlawful detention and imprisonment without trial of political opponents, flagrant disobediece of court injunctions by political leaders as well as the falsification of election results which have led to the cancellation of election results in some states of the Federation and the removal of governors, members of the state and national houses of assembly on the ground that their election results were forged are manifestations of Machiavellianism.

Since amoral practices characterize the country's politics, we contend, that the citizens have no moral obligation to obey the state. This is because their interests are no longer being represented; rather the whole activity reveals the efforts of the leaders towards the realization of their selfish private interests.

Apart from the above, it should also be pointed out that the exercise of political power in this way entails some sort of compulsion, oppression and denial of freedoms. It makes the public to live in perpetual fear. Leadership in this regard in Nigeria has, therefore, become autocratic and dictatorial. Once political leaders acquire power, they refuse to be accountable to the public and become so corrupt in their dealings. To buttress this view, Omoregbe $(1993,127)$ argues that "remove morality, remove honesty and public accountability, and what are governments but gangs of thieves and treasury looters". The point of emphasis in Omoregbe's assertion is that, any government made up of dishonest, fraudulent people who have no other intentions of coming to government than to steal, kill and destroy in order to enrich themselves is not a government.

The Nigerian political situation after independence can be described as a complete privatization of the state by the few political elites who were voted into office (Adegboyega, 2010, 63-67). This is because those that were voted for, to lead the people only explored the opportunity for selfish acquisition of wealth by making governance a personal affair. As it is often believed, democracy is the type of government that always ensures the rule of law, transparency, and accountability of the rulers. These virtues are repugnant to many of the Nigerian leaders. So, they refuse to submit to the norms of political morality and swear to false oath.

The second premise of our argument discussed and considered amoral above follows from the first. Machiavelli's political idea supports injustice in the acquisition and retention of political power as well as in the 
exercise of political power. This is also found in the Nigerian politics, and this situation simply shows a betrayal of justice by Nigerian leaders. However, justice is a fundamental virtue in the governance of any society; it enhances the pursuit of common good.

This view is corroborated by John Rawls' conception of justice, which gives adequate consideration to every member of the society. The principle of justice, Rawls argues, determines how the benefits and burdens of society are to be distributed among individuals in a fair manner. Thus, for Rawls, justice equals fairness. Yet how can people determine what is fair, especially in society of great inequalities and diverse interpretations of good life? Rawls theorized that the principle of fairness is that which would be agreed upon by people in a hypothetical situation he referred to as the "original position" (Rawls, 1971, 2-4).

Imagine, Rawls said, that humans are disinterested moral agents which do not know the particulars of their situations in life, including race sex or economic status. Rawls believed that in this original position people would agree on two principles.

(i) That each person is to have equal right to the most extensive liberty compatible with similar liberty to other individuals.

(ii) That any social and economic inequalities should be equally available to any position and should provide the greatest benefit for the least advantaged.

His resulting view, known as the difference principle, implied that no advantage can morally exist if it does not benefit the most highly disadvantage.

An examination of Rawls principles of justice shows the idea of justice as a complex of three ideas. These are liberty, equality, and reward for services contributing to the common good. We must stress that this second principle called the difference principle stands at the core of Rawls' theory and it intends to capture the fundamental fact of the equality of all people. That is, the substantial equality of everyone to an equal claim in the share of the socially generated wealth. His belief is that this substantial equality does not account to claim to an equal share of wealth. An objection to his view states that this arrangement will facilitate undue inequality in the appropriation of wealth. Rawls argues that there is bound to be a disproportionate allocation of wealth, but this does not invalidate the just nature to that society. Rawls also introduces implicitly in the difference principle, the view that the disparities is only just as the wealth of the affluent contribute to the improvement of the worst off. He also argues for the lexical ordering of the two principles in favour of the principle of liberty should there be an occasion for conflict between the two. Rawls position simply emphasizes the relevance of justice to human society and the need for proper ordering of resources in such a way that peace, unity and social order may be attained.

Thus, when the leaders in any nation neglect the path of justice, then such nation is doomed. Remove justice says St Augustine "and what are kingdoms but gangs of criminals on a large scale" (Omoregbe 1993, 127). St Augustine's view is that justice is so essential to governance. Injustice in Nigeria has bred nothing but insecurity in the political, economic and social arena. It is equally one of the causes of political instability in the nation. The reasons for this is because, once the people realize that they cannot get justice from government, they take laws into their own hands. This has resulted in the various ethnic conflicts, strikes and other forms of social unrests. The inability of the citizens to get justice and the persistence of unequal distribution of the resources of the nation has also made the people to be dishonest to the nation. Some citizen with a little exception engages in various immoral acts such as stealing, money rituals, bribery, killing, kidnapping, vandalization of oil pipelines and so on. These actions are antithetical to social order and national development.

Third, the attempt by Nigerian politicians to separate morality from politics as suggested by Machiavelli undermines the loyalty of the citizens who give them the power. This argument is premised on our understanding of consent and elections in political processes. Through this processes, every group surrendered their freedom to be managed by the leaders so that there may be an enforcement of order, maintenance security and justice among members of the state. It is on this ground that the citizens become politically obliged to obey their leaders. But, the abuse of this principle by the leaders began when they no longer have the interest of the people who gave them the power at heart. Such attitude is a disservice to the people. It also follows that the state has failed in promoting political and indeed public morality that is fundamental to the pursuit of common good, because of the leaders' attitude.

\section{Machiavellianism, Public Immorality and the Future of Nigerian Politics}

Two important questions that agitate our mind here are: one, can't politicians do other than act immorally? Michael Walzer $(1989,192)$ put the question better when he asks; "can a public officer govern justly or 
innocently?' Two, can the above discussion of Machiavelli be adjudged the best and correct interpretation of his principle?"

The first question raised by Walzer can be reframed as: is it that we cannot have decent people with good intentions of general reformation in politics? The answer to this question can be in the affirmative. But, when we consider the nature of politics in Nigeria, we can conclude that such people may not on the long run, be able to achieve the good goals of politics. This is because, in the end, their attempt to be good may either put them against certain members of the society who will have everything to work against these good politicians or, they please some other members who appreciate every step they take. Machiavelli ascribes these possibilities to human nature as corrupt and wicked (Ozumba 1997, 129). He, therefore, encourages such leader not to commit himself or herself to moral principles because it may lead to his ruin. Such leader must learn to be good and bad. In other words, those who will appreciate the leader's effort, the truth may be revealed to them and moral reasoning be employed in dealing with them. But, for those who will always be displeased, he might have to deceive them into believing his ideas. What should be of interest to him is that he is able to achieve his end.

Moreover, since the politician is not serving the people only but also serves himself, the situation is that if he will have to retain the power and the glory attached to it, he may be left with no option than to accept Machiavelli's suggestion. Reasoning along this line of thought, Michael Walzer contends that a politician cannot but sometimes soil his hand with certain immoral means. The reason for this is that, while he may want to profess being good, there are other people who are contesting for the same power and glory and who would want to win at all cost. This may make them to adopt immoral means. It is on this ground that Walzer $(1989,192)$ asserts; "No one succeeds in politics without getting his hands dirty". Besides this, politicians sometimes get the public convinced or make them to support their policies only by deceiving the public to believe such policies.

Furthermore, in the contention for political power, human instincts and reason play vital roles. Human being has to reason out how and what to do in order to achieve his end. This involves both moral and immoral means. Sometimes immoral means could be useful, that is, telling lies or deceit, to acquire and retain political power. A politician who wants to stop corrupt practices in the nation will invoke the wrath of those who benefit immensely from it and so may not have their support for him to be the leader. Thus, if he fails, his good intention cannot be realized. He would have to employ some immoral means like pretence, make deals with the dishonest boss or people, to gain their support in his bid to rule.

In matters of politics therefore, we cannot condemn the intention of the good politicians to reform or look at him failing to acquire what will enable him to implement the good intention. A critical analysis of Walzer's view will, therefore, show an approval of the view that to determine the moral value of such action and other political actions, there is the need to critically examine the particular circumstance in terms of reasonable alternatives, available knowledge, and likely consequences. Second, moral rules should be considered as guidelines and summaries of previous calculations that can ease human choice in ordinary cases. This is because, it is possible for man to follow injunctions and do what has been found useful in the past. It appears to us then, from the above that Michael Walzer gives credence to Machiavelli's idea but in a new dimension. However, we must ask if an evil means can be used to resolve a problem created by evil. The answer is, "no".

Fifty-four years after independence, Nigeria is still underdeveloped. The nation lacks focus and seems to be operating in a political ideological vacuum. The simple reason for this is not because the nation lacks the natural and human resources that can enhance development, but because of leadership's exemplification of the Machiavellian politics, which encourages them to exercise power without any moral consideration. Contrary to this, lack of development has always been blamed on the direct evil of colonialism of the nation, the citizens and the political class.

The above notwithstanding, our opinion is that, fifty-four years is long enough for Nigeria to learn, plan, change and adopt a better and more suitable political ideology that can enhance growth and development. We acknowledge whatever evil influences colonialism might have on the possibility of development in Nigeria. Some of these are; first, the destruction of the old existing traditional political system that was fashioned after the culture of the people. Second, is the lack of adequate political education about the newly introduced political system and all its values and principles. Three, is the destruction of the traditional religious beliefs and practices, which prohibited any form of immoral practices and the instant punishment of any defaulter by the gods. This as we know, is not like the kind of judgment that we often see in the western religion, which is characterized by delay. The fourth is the introduction of money into politics, political corruption and so on. But then, our argument is, since independence those who have occupied the positions of authority have dined and wined with the colonizers. Therefore, they ought to have learnt lessons on the real ideals of politics and other ideas that can 
aid national development if their interest is to serve the country. This has not been the case. The questions that can then be asked are: Is it the case that our people had refused to learn? Or, is it the case that the colonialists refused to teach and tell our leaders the truth about the new political idea they left us with? Whatever the answers may be, what we have observed is that political practice in Nigeria lacks moral consideration. Unlike in the Western countries, power is no longer seen as an end in itself, this is not the case with Nigeria where politicians struggle for power to actualize selfish purposes. Also, no political ruler in Nigeria is always willing to leave the position of governance even after the expiration of his or her tenure of office. An example was the failed Third Term Agenda of the Olusegun Obasanjo's regime (Olaiya, Apeloko \& Ayeni 2013).

Though, a wrong political arrangement was inherited from the colonizers, it is not a sufficient and immediate reason for the political immorality that persists in the contemporary Nigerian society. The central problem is that politicians have refused to learn, understand, and know that politics is not a disservice but that it is service to a nation. An analogy can be drawn to support our claim. For instance, that I inherited a dilapidated building from my master whom I have served for many years is not a sufficient reason for my not making effort to repair it after handing it over to me. Also, that Jingo inherited a disease from his adopted parent does not presuppose that he should not make efforts to look out for a cure. But, is Nigeria making any effort to change the unfavorable political culture inherited from her colonizers or not? Depending on one's will power to make a change, political leaders have made efforts but these efforts have not yielded much fruit because they are also part of the problem.

A more recent experience confirms the above claim. The 2003 and 2007 general elections in Nigeria show that political corruption was highly perpetrated. Reports after the elections showed that there was massive rigging. This was attested to after the 2007 general election by the late President Sheu Yaardua that the election was rigged (Tribune 2007). The question then is, is there any future for Nigerian politics. If yes what steps must we take to address the endemic virus of political immorality in our nation?

Machiavellian conception of politics shows a process that has gone out of order in Nigerian politics. It is an abnormality that must be corrected. The struggle for power is like every other human desire. It must be subjected to moral control. If it is not, then the Nigerian state may be heading towards the situation of the state of nature, which Hobbes describes as "nasty, brutish and short". The problem of political corruption is like a virus in a human system that can lead to his death. So, it deserves nothing but a cure. If not, all the various forms of social disorder that we are currently experiencing may take a faster destructive dimension which may lead to total disintegration of the nation.

Political corruption has become a virus that now manifests in all areas of the nation's politics. It rare its head in various forms and shapes. Some of these are: Official lawlessness which is common among public officers and mostly uniform men like police; introduction of money into Nigerian politics, which is often done by politicians to mobilize support during elections: political manipulation, this takes various forms, like, rigging of elections; breakdown of rule of law; injustice and so on. All these and other vices are responsible for the high poverty level, low life expectancy, unequal distribution of income, instability, ethnic rivalry, lack of trust, thuggery, social disorder and underdevelopment (Adegboyega 2010, 43). The crisis of political corruption threatens the process of democratization and development in Nigeria. It has redefined the concept of politics in the nation, and it has affected the political culture of the country. It runs across the, executive, legislative, judiciary political parties, labour and traditional rulers.

It behooves us to ask some very pertinent questions here, for example; "Is it justified to describe Machiavelli's principle as immoral? Is there no lesson that can be learnt from Machiavelli's principle? Answers to these questions must examine the socio-cultural events that surrounded the ideas, which Machiavelli expressed in his book, The Prince: There is also the need to examine the ultimate intentions of Machiavelli or what he attempts to derive from the approval of these immoral principles for political practice. Was he interested in creating an anti-moral society? Our answer to this is, no, given our understanding of the social-cultural events of the time in Italy, which was characterized by immorality and instability. Machiavelli was interested in providing a political ideology that could resolve these problems and reinstate unity in Italy.

Reasoning from the phenomenon before him, and accepting as a precedent the general course of Italian politics, he could only find the remedy in material force and unscrupulous cunning. He consequently longed for the coming of a deliverer, a man of strong and indomitable will with iron hands capable of reconstructing and unifying the whole country. The means by which the person would accomplish this was of no relevance, provided Italy is saved from her ruin and be made to attain strength and independence as a great European power. This we are able to deduce from the Chapter Twenty-Six of his book The Prince that contains his appeal to Lorenzo de Medici to save Italy. 
Unlike in the Nigerian society where politicians see evil as a means of attaining a selfish end and, therefore, employ it to destroy the political morality that supposed to herald peace, unity and social-order in the system, Machiavelli condones evil not for its own sake but only as a means that any prince that is interested in social-order, unity and development of the Italian state could adopt it. One important question that agitates the mind here also is whether the principles contained in the book were meant only for the Italian State? This perhaps is a difficult question, more so when we consider the various examples he has drawn from past history of other nations to establish how those Princes who adopted the diabolical nature were able to succeed and how those who embraced virtue lost their thrones. Bearing this in mind, we argue that Machiavelli provided the principles for any would be Prince to learn from how to acquire and retain himself in power. Also, that any form of principalities that found itself in this situation, if they adopt his principle would in the end help to restore peace, unity, and progress in such state or nation. It is on this premise that Machiavellian politics is generally adjudged to be amoral, not only with specific reference to his society, but to all political societies. An important point that we must remind ourselves is that immorality characterized his society ever before his attempt to write his treatise that sounds amoral.

For ordinary reader of Machiavelli's The Prince, his doctrine sounds immoral, but it is obvious that it cannot be so characterized by those who hold the belief that the true basis of morality is utilitarianism. Utilitarianism is an ethical theory that "determines what is right or wrong by considering what will have the best consequences for the welfare of sentient beings or, more accurately, produce the greatest balance of good over evil in the world as a whole" (Frankena \& Granrose 1974, 127). This definition shows that the utilitarian is concerned not only with the consequences of human actions and rules, but also with the consideration of the good and evil in those actions that is, with the total good and evil brought about by the action and nothing else. Thus, when we apply their view to Machiavelli's dictum 'the end justifies the means,' this view cannot possibly be taken to characterize the immoral position of Machiavelli. Assessing Machiavelli's idea, Henry Sidgwick (1987, 1) asserts that to Machiavelli, the end "must always ultimately justify the means... The only condition however, is that such end must be a general end; not the preservation of any particular individual or group". The end must focus or be for the unity happiness and well-being of humanity at large. We argue, therefore, that the immorality of Machiavellianism does not lie in its affirmation that the practice of all moral rules in politics will yield a bad consequence or end. The immorality only begins when the end in view and the regard for consequences does not take into consideration (as a paramount task) the interest of the whole state or nation which is the basic concern of Machiavelli.

The way Machiavelli's principle is adopted by politicians in Nigeria and by many other politicians after Machiavelli himself is in contrast to the real intentions of Machiavelli. The adoption of Machiavellianism as noticed in Nigerian politics is for selfish interest, for this reason it collides with the idea of morality. It may perhaps be said that Machiavelli's recommendation of the principle as a paramount end for national interest's sake does not necessarily make the principle to be involved in a collision with established morality. The intention of Machiavelli is to show the belief that veracity and good faith or that virtue and vices are always the best policy for states and for individuals depending on the situation of the state. If we follow this view, then Machiavelli's belief is not that tyranny or despotism is the best form of government, but that it is the best form of government in a corrupt society. To really understand Machiavelli's political theory, one has to read another work of Machiavelli "DISCOURSES". It is in this book that Machiavelli's picture as a democrat is shown as well as his commitment to the fact that the best form of government under normal circumstances is democracy. However, in a politically corrupt and weak society, characterized by instability, social disorder and economic imbalance and so on, democracy would not work. To rule such a corrupt society successfully, a ruler has to be ruthless, sometimes brutal and cruel, but at the same time crafty as stated in THE PRINCE.

The above view raises fundamental question about how a ruler who has no regards for moral ideals simply because of his goal can possibly command the obedience of the people and thereby rules efficiently. It also raises question on what the nature of political obligation would be from the state to the citizen and from the citizens to the state. Suffice to say here that the concepts of obedience, political and moral obligations bear on the idea of morality. Political morality is the observation of certain ethical norms that guide political practice. Strict adherence to these norms is considered important for the achievement of the purpose for which the society is created, that is, the promotion of the common good. The basic truth of political practice is, therefore, that morality should not be divorced from politics. This is premised on the claim that politics is a human act, and morals are standards used to judge human acts. Another vital point is that the idea of power is central to politics, and it is not debatable that power is good but unlimited power is bound to be a source of evil.

Furthermore, Machiavellianism exhibits a maxim of unscrupulous tyranny and seems to advise the despots on 
how to coerce and enslave his subjects, a maxim that we all need to reject in its entirety. The adherence and practice of this maxim by the political elite in Nigeria has subjected Nigerians with a very few exception under the control of the leaders. The result of this is the high poverty level of an average Nigerian. It has also made Nigerians to be skeptical about their future existence. Describing the effects of this maxim on human race, Settembrini (Owen 1970, 174) affirms that Machiavelli's statecraft may be likened to the traditional cherubs, all heads and no hearts.

Notwithstanding all the above shortcomings, critics have argued that Machiavelli in rejecting the validity of the doctrine of moral philosophy for the conduct of politics has established politics as an autonomous field. Felix Gilbert (Edward 1967, 121) states that Machiavelli could do that because he rejects political bodies not as creation of humans' reason but as a natural phenomenon. To Machiavelli, all political organizations be it animals, plants and human are subject to the laws of nature. They are born, they grow to maturity, they become old and they die. Well-organized political bodies might survive longer than others, but even the best-constructed political society cannot escape decline and death.

Beside the above, we must acknowledge Machiavelli's insight that the state can be understood only in terms of human appetites and his recognition that the successful ruler must learn to control these forces that mark an epoch in political thinking which constitutes the whole modern development. On this, W. T. Jones $(1980,50)$ expresses that Machiavelli, more than any other individual and despite the fact that he is hardly a political theorist, is the father of modern political theory. He makes the first decisive break with the thought of the Catholic Middle Ages on political problems. This idea makes the state to become a natural entity that emanates and exists amidst a play of natural forces. The ruler must understand this and make use of his ideas if he and the state are to survive in the ruthless competition of existence. In this regard, Machiavelli laid the foundation for Marx and other later theorists who reduced politics to the study of power conflicts and control. But, we wonder if Machiavelli's conception of political power can bring social order to the society as the Nigerian experience suffices.

\section{Conclusion}

The manifestation of the negative influence of Machiavelli's kind of politics on the Nigerian society is obvious. As pointed out earlier, it has led to the lack of public morality in the Nigerian polity. The situation now is such that the individual has not only lost confidence in the leadership of the nation but also that the individual now feels that adherence to civic virtue or sense of honesty is a kind of insanity or foolishness. There is a conception that the poor ones who are honest are the non-smart and stupid ones. The need to survive has now become the responsibility of the individual, that is, what the individual can do on his or her own whether moral or otherwise. This has not only led to the formation of various groups such as religious, ethnic militias, but has also made people to get involved in violence, robbery, killing and other social vices for their survival. Commitment and loyalty have been shifted away from the state to either the individuals or their immediate groups. These problems and series of experiences and information on thuggery, killing, deceit, injustice persists. All these have placed the nation under perpetual insecurity, social disorder, lack of growth and underdevelopment. For a nation to develop, social and political security is fundamental as it has multiplier effects on the human, economic, technological development and other sectors of the society.

As observed from the above discussion, the manifestation of Machiavellianism in the Nigerian political practice has offered the nation a negative experience and it is a pointer to the fact that the future of Nigerian politics is bleak. The realization of the promises and goals of independence as well as the hopes of our patriarchs who fought for it, to have a nation where peaceful coexistence, unity, justice, freedom and human rights reign supreme is uncertain. To prevent all the evils that result from Machiavelli's philosophy, we argue that the misinterpretations of Machiavellianism should be discontinued so that the Nigerian society can move forward in this new millennium. Thus, the hope of a better future for Nigerian politics lies on the readiness of the political elites to jettison the Machiavellian notion of separating morality from politics. Morality should be given utmost consideration in political practice. Only this can make the citizens to have faith and hope in the leadership of the country, and restore their confidence in the political elites. It will also promote the political and moral obligations of both the citizens to the state and the state to the citizens. This we believe will place the nation on the path of growth and development in the twenty-first century.

\section{References}

Aajanaku, I. (2006, January 4). Rasheed Ladoja impeached. Guardian News Paper, p.1.

Adegboyega, O. O. (2010, April, 5). Politics and the Nigerian situation. International Journal of Advanced Legal Studies and Government, 1(1). 
Adegboyega, O. O. (2012). The dearth of public morality in Nigeria. International Journal of Arts and Culture in Society, 4(3), 63-67.

Ademoyega, A. (1981). Why we struck. Ibadan: Evans Brothers.

Agbonifo, E. (2012). Ngige and Obasanjo's moral blunder. Retrieved from http://www.vanguardngr.com/2012/09

Alemika, E. O. (2012). Corruption and insecurity in Nigeria. In R. A. Durojaiye, E. A. Unobe, \& R. Sanusi (Eds.) Proceedings of the Amadu Bello University@ @0, Humanities International Conference. Zaria: ABU.

Appadorai, A. (1975). The Substance of Politics. Maras: Oxford University Press.

Edward, P. (Ed). (1967). The Encyclopedia of Philosophy (Vol. 5\&6). New York: Macmillian Press, 121.

Ekeh, P. P. (1975). Colonialism and the two publics in Africa: A theoretical statement. Journal of Comparative Studies in Society and History, 1(1). 91-112. http://dx.doi.org/10.1017/S0010417500007659

Ekeh, P. P. (1980, June 5). Colonialism and the social structure. An Inaugural Lecture delivered at the University of Ibadan.

Ekeh, P. P. (1998). Theory and curses of military rule and the transition programme. Association of Nigerian scholars for dialogue. Retrieved from http://www.waado.org/nigeriascholars/archive/theory.html

Etim, F. O., \& Wilfred, U. I. (2012). The impact of military rule on democracy in Nigeria. Journal of Social Science, Kalma-Raj, Indian, 33(3), 285-292.

Fagbemi, T. (2007, February 28). Obasanjo, Atiku abused their office. Nigerian Tribune.

Frankena, W. K., \& Granrose, J. T. (1974). Introductory Readings in Ethics. Englewood Cliffs, New Jersey: Prentice-Hall.

Gboyega, A. (Ed.). (1996). Corruption and Democratization in Nigeria. Ibadan: Friedrich Ebert Foundation and Agbo Areo.

Jones, W. T. (1980). Master of Political Thought: Machiavelli to Bentham. London: George G. Harrap and Co. Ltd.

Machiavelli, N. (1975). The Discourses. Trans. London: Routledge and Kegan Paul.

Machiavelli, N. (1999). The Prince (G. Bull, Trans.). London: Penguin Books.

Maduabuchi, D. (Ed.). (2003). Philosophy and Politics: Discourse on Values, Politics and Power in Africa. Lagos: Malthouse Press.

New York Times. (2004, August 19). Late Nigerian dictator looted nearly \$500million.

Nigerian PM. News Paper. (2006, August 14). Professor Ayo Daramola, Ekiti gubernatorial aspirant assassinated.

Nigerian Punch News Paper. (2006, July 28). How Funsho Williams was killed.

Nigerian Punch News Paper. (2010, January 25). Dipo Dina, Ogun Opposition Politician Assassinated.

Ogunmodede, F. I. (1986). Chief Obafemi Awolowo's Socio Political Philosophy: A Critical Interpretation. Italy: Tiopo-Litografa.

Olaiya, T., Apeloko, D., \& Ayeni, O. O. (2013). Factors in Mass Media, $3^{\text {rd }}$ Term agenda and governance in Nigeria. International Knowledge Sharing Platform. Retrieved from http://www.iiste.org/ionas/index

Omoregbe, J. A. (1993). Ethics: A Systematic and Historical Study. Ikeja: Joja Educational Research and Publishers.

Owolabi, K. (1995). The dearth of public morality in Africa: Towards a restoration and restitution. Africa Quaterly, 35(3), 3-8.

Ozumba, G. O. (1997). The Great Philosophers Vl.11. Aba: Vitalis Books.

Pieth, M. (2008). Recovering Stolen Assets. Peter Lang.

Prodanov, V. (1980). Morality and Politics in a Changing World. In A. Toffler (Ed.), The Third Wave. Toronto: Bantam Books.

Raphael, D. D. (1982). Problems of Political Philosophy. London: Machmillan Press.

Rawls, J. A. (1972). Theory of Justice. Oxford: University Press. 
Sher, G. (1987). Moral Philosophy: Selected Reading. Chicago: Harcourt Brace Jovanovich Publishers.

Shosanya F. (2009, August 30). The pains and loses of pipeline vandalism. Daily Trust, Nigeria.

Sidgwick, H. (1987). "Practical Ethics". An Essay read on January 26, 1987, at a meeting of a Cambridge Essay Club called "The Eramus."

Sturzo, L. (1983). Politics and Morality. London: Burns \& Wash Bourne Ltd.

Walzer, M. (1989). Critique of Philosophical Conversation. Philosophical Forum, 2(2), 192.

Werlin, H. H. (1972). The Role of Corruption: The Ghanian Enquiry. Journal of African Studies, 10(2), 395.

\section{Copyrights}

Copyright for this article is retained by the author(s), with first publication rights granted to the journal.

This is an open-access article distributed under the terms and conditions of the Creative Commons Attribution license (http://creativecommons.org/licenses/by/3.0/). 